\title{
The Cold War and Western Perspectives on Soviet Science ${ }^{1}$
}

\section{A Guerra Fria e as perspectivas ocidentais sobre a ciência soviética}

\author{
CLIMÉRIO PAULO DA SILVA NETO \\ Universidade Federal do Oeste da Bahia | UFOB
}

\begin{abstract}
This essay presents an overview of the dominant trends in the Western historiography on the Soviet Union along the Cold War inquiring how they affected the perspectives on the history of Soviet science. It discuss three major trends, namely totalitarian school, which resonated with Robert Merton and Karl Popper's claims that science best develops in democratic societies; the revisionists, which came of age in the 1960s and resembled some schools of the sociology of science both in their motivation to subvert the dominant perspective in their discipline and in their methodological choices; and, finally, the post-Cold War and post-revisionists perspectives on Soviet history and history of Soviet science, and how they challenged widely held beliefs on Soviet science and society that underpinned many Cold War-era works on the Soviet Union. The conclusion discussed how the historiography of Soviet Science resonates with Christopher Hill's claim that history needs to be rewritten at every generation.
\end{abstract}

Keywords Soviet Union - Soviet science - science and politics.

RESUMO Este ensaio apresenta uma sintese das perspectivas dominantes sobre a ciência soviética ao longo da Guerra Fria buscando entender como elas refletiram nas perspectivas dominantes sobre a ciência soviética. Três principais tendências são apresentadas. A saber, a interpretação totalitária, que ressoava com as visões de Robert Merton e Karl Popper de que a ciência se desenvolve melhor em regimes democráticos; os revisionistas, que se assemelham a algumas escolas de sociologia da ciência tanto em sua motivação para subverter as perspectivas dominantes em sua disciplina quanto em suas escolhas metodológicas; e finalmente, as perspectivas pós-revisionistas surgidas após a queda da União Soviética. A conclusão discute como a historiografia da União Soviética ressoa com a afirmativa de Christopher Hill de que a história precisa ser reescrita a cada geração.

Palavras-chave União Soviética - ciência soviética - ciência e política.

Not to laugh, not to lament, not to curse, but to understand. ${ }^{2}$

\section{Introdutcion}

Science was a central element of the Soviet Union throughout its existence, regarded by official ideologues as essentially entangled with society. Not only its direction, but its structure and demographics were supposed to be determined by social needs and policies of the Communist Party, which in turn, offered unprecedented financial support for science. Along the history of Soviet Union scientists and government developed a complex and multi-faced relationship that resulted in the world largest scientific establishment, equally complex and multi-faced. For those and other reasons, 
Loren R. Graham, the dean of history of Soviet Science in the West, has argued that one can hardly imagine a case better suited for testing our contemporary ideas and theories regarding science, technology, and society than the historical experience of Russia and the Soviet Union. ${ }^{3}$ Alexei Kojevnikov, echoing Graham, highlights that "the Soviet case was characterized by, on the one hand, an exceptionally high development of science and, on the other hand, a distinctive social and cultural milieu artificially isolated from most international contacts by political barriers. This exceptional combination offers historians a perfect opportunity for genuinely comparative studies of science and society." ${ }^{4}$ Hence, history of Soviet science certainly deserves the attention of the communities of historians, sociologists, and philosophers of sciences at large, and above all of those interested in the relationship between science, politics and ideology. More than in any other country, perhaps with the exception of the United States, science in the Soviet Union has received a significant share of attention of foreign scholars, specially since the beginning of the Cold War, and the ensuing literature indeed offers valuable insights on the nature of scientific knowledge. However, as Soviet science itself, that literature has been strongly influenced by the tides and political passions of the Cold War. With this in mind, I endeavored to write this historiographic essay with an overview of the evolving perspectives on Soviet science in the last half-century. My strategy was to look at the dominant trends in the Western historiography on Soviet Union along the Cold War inquiring how they affected the perspectives on history of Soviet science. ${ }^{5}$ Hopefully this paper will stimulate other students of science to become more familiar with Soviet science and embrace this "perfect opportunity for genuinely comparative

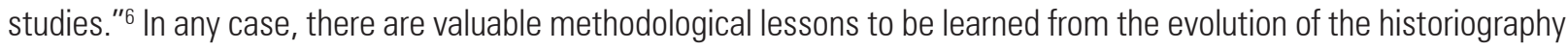
of Soviet science.

The history of Soviet science is at the intersection of two sub-disciplines, namely the history of science and Soviet history, that have evolved along similar lines in the last half century and in the last decades have relied on methods of social and cultural history. The similarity is not surprising, though, if we consider that both sub-disciplines have been affected by the cultural and intellectual climate of the Cold War and key events such as the anti-communist hysteria of the late 1940s and 1950s, which favored a scholarship framed in terms of the binary opposition between the "totalitarian East" and the "democratic West"; and the protests of the late 1960s, which favored contentious scholarships as the revisionists in history of Soviet Union and the constructionists in history and sociology of science. Perhaps, however, it was the end of the Cold War, and the ensuing integration between the Eastern and Western communities of historians, added to the influence of developments in the academic discipline of history (the linguistic turn) that caused the clearest convergence between Soviet history and history of science.

Assuming that the reader is more familiar with the evolution of history of science and science studies, which have been the subject of a dossier in a recent issue of this journal, ${ }^{7}$ in this essay I dedicate more attention to developments in Soviet history and its impact on history of Soviet science. Then, in the next section I discuss the totalitarian interpretation of Soviet Union, which resonated with Robert Merton and Karl Popper's claims that science best develops in democratic societies. Next, I turn to the challengers of the totalitarian school, a group of social historians self-professed revisionists which came of age in the 1960s and resembled some schools of the sociology of science both in their motivation to subvert the dominant perspective in their discipline and in their methodological choices. In the section 3 I discuss the post-Cold War and post-revisionists perspectives on Soviet history and history of Soviet science, and how they challenged widely held beliefs on Soviet science and society that underpinned many Cold War-era works on Soviet Union. I conclude the essay discussing how the historiography of the Soviet Science resonates with Christopher Hill's claim that history needs to be rewritten at every generation.

\section{Totalitarians and Mertonians}

In the aftermath of the World War II, as the Soviet Union replaced Nazi Germany as the enemy number one of Western civilization in the perspective of European and North-American Cold Warriors, Western scholars began attentively studying what was going on behind the Iron Curtain. Kremlinology and Sovietology acquired strategic significance and 
were highly stimulated in North American Universities, attracting a few bright minds. Then, the order of the day was "know your enemy." An emblematic case of this period was the creation of the Harvard University's Russian Research Center. In 1947 the Carnegie Corporation, diagnosing a shortage of "serious work on Soviet behavior in Washington," convinced Harvard professors to accept money to create a research center dedicated to Russian studies. The first head of the Center, the anthropologist Clyde Kluckhohn, knew almost nothing about Russian language and culture at that time. However, he was an old acquaintance of military agencies. During the WWII he had worked at the Foreign Morale Analysis Division of the Office of War Information studying the Japanese culture. Afterward, considering the wartime work a great success, Kluckhohn energetically promoted their methods of studying "culture at a distance."8

The Harvard team and other similar centers then created to promote Soviet studies developed ingenious methods to interpret what was going on inside the Kremlin and how it maintained pervasive ideological control on the population, the most likely means being terror and coercion. The Soviet Union, despite having led the anti-fascist resistance, under this light came to resemble the fascist states and had its similarities with Hitler's Germany emphasized under the label "totalitarian state." Those studies forged the so-called totalitarian framework that dominated the studies on the Soviet Union until the late 1960s. They formed a sophisticated, although one-sided, view of Soviet Union "from above," which focused on high politics and the ideological foundations of the regime, paying due respect to Marxism-Leninism as the motor behind the Soviet project, but neglected agency to Soviet society. ${ }^{9}$

Much of the scholarship done in the heydays of the totalitarian school, the 1950s and 1960s, was framed in terms of the binary opposition between the "totalitarian East" and the "democratic West." In history and philosophy of Science, the thesis that science and democracy reinforced each other forged by Robert Merton and other intellectuals in the late 1930s, in the context of the rise of fascism in Europe, was endorsed by the philosopher of science Karl Popper in the 1950s. The purported separation between science and ideology of the "democratic West," often seen as a uniform whole, was contrasted with the supposedly dangerous mix of science and Marxist ideology practiced in the Soviet Union. ${ }^{10}$

In the late 1950s, the totalitarian framework began to crack from within. David Engerman in his essay on social sciences in the Cold War gave two instances of military projects whose results questioned the basic assumptions of the totalitarian model. ${ }^{11}$ First, in the early 1950s the Air Force paid $\$ 1$ million (almost $\$ 55$ million in current dollars ${ }^{12}$ ) to Harvard's Russian Research Center to make a "Working Model of the Soviet Social System" based on interviews with refugees. In publications and classified reports, Kluckhohn and his team concluded that the "Soviet regime had wide if not deep support from its citizens, and was not teetering on the brink of collapse; American forces attacking the Soviet Union, in short, would not be greeted as liberators." Contrary to expectations, they concluded that the Soviet Union was a stable industrial society, in important ways similar to the United States. ${ }^{13}$

The second military project whose results questioned the basic totalitarian assumptions was the Smolensk Archive, the first archive available to Western social historians of the Soviet Union. In 1941, when the German Army invaded the city of Smolensk, close to the Western borders of Russia, it managed to take a large part of the local archive of the Communist Party. The archive contained a wealth of documents and letters from citizens and Party official, which offered a window into a micro-cosmos of the USSR. Upon the defeat of Germany, the American Army found and claimed the archive, which in turn, passed through the CIA, the US Army Air Force, and was finally given to RAND (Research ANd Development) Corporation, a Global policy think tank created by the Air Force "to help to improve policy and decision making through research analysis". ${ }^{14}$ The first analysis of that archive was published in 1958 by Harvard political scientist Merle Fainsod in the book Smolensk under Soviet Rule. According to Engerman, it "offered a devastating empirical challenge to the notion that the Soviet Union was under total control of a small group of schemers in the Kremlin; 'the totalitarian facade,' Fainsod concluded, 'concealed a host of inner contradictions.' Indeed, he drew attention to 'surging energies from below' that would become 'the seedbed of tomorrow's political debates."'15

In addition, the totalitarian framework, which already had difficulty to explain how the Soviet Union had won a total war that required an enormous sacrifice from its population based on terror and coercion alone, became even more fragile when, after Stalin's death in 1953, the Soviet Union exhibited itself as a prosperous economic, scientific, 
and military power under the more loose policies of Khrushchev's Thaw. ${ }^{16}$ The difficulties faced by the totalitarian framework, added to the subversive mood set by the protests against the Vietnam War, favored the emergence of alternative interpretations of Soviet history.

\section{Breaking paradigms: The revisionist challenge}

The main challenge to the totalitarian school and works based on its premises came from outsiders, the cohort of social historians self-professed revisionists led by Sheila Fitzpatrick, an Australian based in the USA, coming of age in the subversive and socially revolutionary 1960s. Then, the Vietnam War was making North American intellectuals painfully self-conscious about the imperialist policies of the United States and the role that science was playing in the defense establishment. In that atmosphere of growing discontentment, the differences between the North American "liberal democracy" and Soviet "totalitarian autocracy" seemed no longer clear cut, and sciences (including social and human sciences) surrounded by a veil of secrecy, no longer seemed so democratic. ${ }^{17}$

More inclined to methods and themes of social history and the view "from bellow", the revisionists objected the "Cold War bias" of the totalitarian school and criticized their framework for being too focused on the Kremlin and its high politics and for treating the population as a formless mass that could be easily controlled by an all-powerful regime, like lab rats on the hands of experimenters. They claimed that based on terror and coercion alone the Soviet Union could not have remained stable for so long, it could not have achieved the impressive industrial growth it did, and it could not have won a war that required an enormous sacrifice from its population. ${ }^{18}$

In works that became classics of the revisionist school, Sheila Fitzpatrick shed light on the impressive social mobility in Soviet Society and the humble origins of the new Soviet elite, arguing that they were loyal supporter of the regime precisely because the regime had created them by a combination of "Cultural Revolution", ${ }^{19}$ term of her creation, and Great Purges. Likewise, based on a study of the lowbrow Stalinist literature of the immediate postwar, another historian, Vera Dunham concluded that there had been a Big Deal struck by the Stalinist regime and the rising middle class, by which the regime provided privilege and accommodation of middle-class values in return for loyalty and support. Taking on Dunham's Big Deal, Fitzpatrick in later work used it loosely to describe the terms of the relationship between the Russian intelligentsia and the regime in the 1930s:

If one hypothesizes something like a deal between the Russian intelligentsia and the Stalinist regime in the 1930s, it would involve the intelligentsia's pledge of loyalty and service to the regime in exchange for privilege and social status for themselves and the regime's support for traditional institutions such as the academy of sciences; and an agreement that the two sides would cooperate in disseminating a popularized form of the intelligentsia's culture among the masses. ${ }^{20}$

The revisionists had much in common with the Edinburgh school of the sociology of knowledge, with which students of science are more familiar. Two of the core explanatory principles of the Edinburgh school, namely the emphasis on interest and the symmetry principle, are conspicuous in the revisionist historiography, which explained both the social support, or lack thereof, to Soviet regime in terms of the "interest" of those groups in society that were identified as its beneficiaries. ${ }^{21}$

Loren Graham, an undisputed pioneer among Western historians of Soviet science, brought a revisionist perspective to the history of Soviet science. In his influential book Science, Philosophy, and Human Behavior in the Soviet Union, he claimed that the natural sciences played a major role in the ideology of the Russian revolution, unparalleled with other revolutions of modern times; and that Marxist philosophy, in turn, was ubiquitous in Soviet science. "Even good science bears the mark of Marxist philosophy, including 'hard' sciences such as physics," he concludes. ${ }^{22}$ In Graham 
historical frame of Soviet science, there was only one major dark spot - Stalinism. For him, Stalin "converted this interest in philosophy of science into a dogmatic interpretation of natural phenomena that rivaled the scholastic system of the

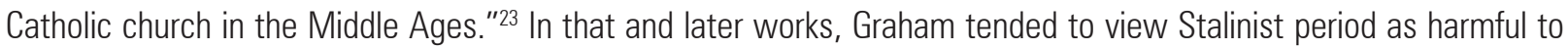
the development of Soviet science ${ }^{24}$ - this turned out to be the dark spot in Graham's nonetheless enlightening work.

In other remarkable revisionist works on the history of Soviet science, one of Graham's pupil Kendall Bailes relativized the negative impact of Stalinism on Soviet science and went further in his acknowledgment of the role of scientists and engineers in shaping Stalinist scientific policies. He stressed that the relationship between scientists and the Soviet government were more complex than the totalitarian model suggests. For Bailes, the prewar Soviet "technostructure" did not simply follow orders issued by the "power structure" but played a significant role in shaping the Soviet social and cultural landscape. ${ }^{25}$ In his last book, about the Soviet mineralogist and geochemist Vladimir Vernadsky and his scientific school, Bailes reveals nuances of the compromise between the old Russian intelligentsia and the Bolsheviks, showing that Vernadsky's scientific stand, his tactful dealing with Soviet officials, and the combination of theoretical and applied research characteristic of his school permitted him to remain an unabashed critic of the official ideology until the end of his life, while promoting his scientific agenda and school under Stalin. Bailes's conclusions show that the regime had only limited control over groups of Soviet society, scientists and engineers in this case, and that the regime's policies were liable to be modified in practice through processes of informal social negotiation. ${ }^{26}$

By the late 1980s, the revisionists had become the dominant Western school of Soviet history. Studying various social groups and showing how their interest agreed or conflicted with the regime's policies, they painted a richer picture of Soviet society, in comparison with the totalitarian school. However, their historiography had problems of its own. One problem, identified by the revisionists themselves with the evolution of their agenda, was that while bringing in the perspective "from bellow" and new themes as social mobility and social support to the regime, they still framed their questions in "Sovietological terms", in the sense that they maintained the focus on a binary relation between society and the government. Studies of social support or resistance took for granted a strict division between society and the state, downplaying the role of social groups as builders, by means other than support or resistance, of Soviet society. ${ }^{27}$

Other two problems of the revisionist historiography surfaced only with the opening of new archives in the 1990s and the arrival of cultural history to the field of Soviet studies. The first is the adoption of a Trotskyist framework to understand the Russian Revolution. ${ }^{28}$ In the context of the 1960s many leftist intellectuals who sympathized with the Russian revolution gladly embraced the idea of a discontinuity between Lenin and Stalin put forward by Trotsky, and later endorsed by Khrushchev. Following this trend, the revisionists tended to see Stalinism as a return, under conditions of great stress, to non-revolutionary traditions under a conservative bureaucracy. However, in the 1990s, as newly open archival sources revealed "Lenin's tough-mindedness and willingness to shed blood", and his "more neurotic and sensitive personality", on the one side; and Stalin as an "intellectual who continued to read seriously even in power" and "dominated his associates partly simply by intellectual power as well as political skills" on the other, it became increasingly difficult to maintain claims that their rule would be qualitatively different, specially the myth of a Lenin gentler than Stalin. ${ }^{29}$ That undermined the Trotskyist framework, and the revisionists were later reproached for adopting a framework to understand the Russian Revolution proposed by Trotsky, "the revolution's greatest loser." 30

The second problem was that building their historiography to a large extent in opposition to the totalitarian school, which emphasized ideology, the revisionists neglected the role of Marxism-Leninism in shaping Soviet society. This too, under the light of new archival sources made available in the 1990s and methods of cultural history turned out to be a problematic feature of much of the revisionist historiography. Based on a wide variety of sources, the following generation, the post-revisionists, criticized the revisionists for neglecting ideology. They would persuasively show the significance of Bolshevik ideology and how it fashioned life in the Soviet Union. ${ }^{31}$ It is remarkable, however, that although the younger post-revisionist generation announced itself as a critic of the revisionists, the latter wisely accepted most of their substantial criticism and welcomed and promoted the post-revisionist historiography. ${ }^{32}$ 


\section{Post-Cold War and Post-revisionist Perspectives on Soviet Science}

The 1990s was a turning point for the history of Soviet science not only due to the opening of new archives, but for a convergence of many factors that affected simultaneously the disciplines of history of science and Soviet history. In the West, specially in the United States, history of science and Soviet history have been strongly influenced by the changes in the political and cultural climate that followed the end of the Cold War, by the integration into the Western communities of Soviet historians who moved west bringing the perspectives of those who had just lived through a revolution, ${ }^{33}$ and last, but not least, by developments in the academic discipline of history as the cultural or linguistic turn of the 1980s, which arrived in those disciplines with a certain delay. ${ }^{34}$

The reaction of historians of Soviet science to the perestroika was two-fold. While some followed the mantra of specialists who dealt with Soviet studies, Westerns and Russians alike, that could be summarized as "What went wrong with the Soviet Union" and "How the Soviet System Failed to Work", seeing nothing but bad in the diseased regime; ${ }^{35}$ others have followed the dominant trend among historians of using the less polarized political climate to develop less biased historical accounts. The latter group will be our main concern here.

The embrace of the cultural turn in the history of science and history of Soviet Union occurred somewhat simultaneously and led to new insights on the power relations in Soviet society and science. The generation of historians formed in the 1990s, the post-revisionists, incorporated elements from both conflicting schools of totalitarians and revisionists adding elements of cultural history to the mix, specially ideology in form of discourse. Challenging "the paradigms of both the parents and the grandparents," 36 they escaped the historiographic dichotomy "from above"/"from below" by framing the interaction between Soviet state and its citizens in terms of a constant renegotiation of power. Learning to "speak Bolshevik", ${ }^{37}$ or to play the "games of Soviet democracy", ${ }^{38}$ Soviet citizens actively participated in the making of Stalinist society. From this perspective, Stalinism was not only a project imposed on Soviet citizens, but also a project of Soviet citizens themselves.

Stephen Kotkin's Magnetic Mountain: Stalinism as a Civilization was a landmark work which set the main agenda of the post-revisionist generation. Based on the creation of the city Magnitogorsk, which he saw as "the encapsulation of building socialism", Kotkin argued that far from retreating from the original ideals of the Russian Revolution, as suggested by Trotskyist interpretations, in the early 1930s Stalin launched a forward-looking and progressive project of building Socialism that transfixed and inspired Soviet people as well as foreign observers. As ideologically formulated, "Stalin's revolution seemed like the second, and potentially more lasting, dawn of a just, merry, and beautiful Russia, where he who has nothing would become everything." ${ }^{39}$ Kotkin thus proposed to "shift the focus from what the Party and its program prevented to what it made possible, intentionally and unintentionally", "without denying the heavy coercive force of the Communist project". ${ }^{40}$

The more permissive cultural and political climate of the Post-Cold War permitted the appearance of other works with similar approaches to Stalinism and similarly provocative titles, such as Alexei Kojevnikov's Stalin's Great Science and Terry Matin's Affirmative Actions Empire, that in earlier years would be enough for their authors to be accused of being Stalinists. ${ }^{41}$ Those works, and others of the same generation, have revealed a side of Soviet history and some of the legacies of the Soviet Experiment that had been shadowed by the ideological climate of the Cold War. They have argued, for instance, that the USSR set the tone for policies that would shape modern societies as the welfare state, affirmative actions, and Big Science. ${ }^{42}$

In the last decades, developing this post-revisionist framework, a younger generation of historians have constructed highly detailed and nuanced pictures of Soviet society under Stalin and have advanced on studies of later periods. Resorting to diaries, oral history interviews, and other printed sources as press articles and memoirs as texts for discourse analysis, they have taken the post-revisionist agenda a step further by including analysis of Soviet subjectivity. ${ }^{43}$ The claims of social support to the regime made by the revisionists, which raised much controversy during the Cold War, have been taken to a new level as historians have emphasized the internalization of Soviet values and code of 
behavior to understand how and why particular groups have become supportive of the regime (Komsomol youth, Jews before the WWII, ${ }^{44}$ and war veterans, for instance). But in addition to that, they have outlined a gradient of attitudes toward the Bolshevik ideology and policies, including the passive resistance by withdrawing from the Soviet project (as the stiliagi counterculture in the 1950s, often compared to hippies) and the appearance of the first dissenters. ${ }^{45}$ For instance, studying youth culture of Stalin's last Generation, Juliane Fürst makes a comprehensive account of youth participation patterns. She argues that they "ranged from ideological commitment to apolitical apathy, from professional careerism to drifting into alternative spheres", being chiefly defined in dialogue with the state and its policies. From hindsight she saw in late Stalinism the seeds of the overturn of the Soviet Union. Up to the end of Stalin's time open dissidence was rare, but disengagement with the official ideology and drifting into alternative, private spheres was enough to destabilize the Soviet system. ${ }^{46}$

The fruitfulness of this perspective in history of Soviet science is evident in Alexei Kojevnikov's Stalin's Great Science: The Times and Adventures of Soviet Physicists, an insightful account that presents a series of case studies that scrutinize the lives of some physicists in Stalinist society on social, political, and ideological levels to make sense of what Kojevnikov called the paradox of Soviet science: "The worst decades of Stalin's dictatorial rule were also the period of arguably the greatest progress achieved by science and technology on Russian soil since the time of Peter the Great". Along his narrative Kojevnikov dismantle many stereotypes largely held during the Cold War such as that the mix of science and ideology is always harmful to science, or that science and democracy develops in tandem and one cannot develop without the other. ${ }^{47}$ Showing how physicists and other scientists engaged with the official ideology and internalized the mores and rules of Stalinist society Kojevnikov illuminated episodes as the polemic Lysenko affair and how scientists, specially the president of the Soviet Academy of Sciences Sergei Vavilov, worked to create one of the World's largest scientific empires.

Another example of work developed in close dialogue with post-revisionist historiography that challenges formerly held views on Stalinist science is Slava Gerovich's studies on the Soviet space program. Gerovich argues that the professional culture of space engineers, with its emphasis on stability, control, and authority, epitomized values of the Stalinist society in which those engineers were formed. And, more surprisingly, that "In the folklore of Soviet rocketry... even the fear and oppression of the Stalin's era were often remembered fondly as productive mechanisms for instilling a strong sense of personal responsibility." Thus, for Soviet space engineers, a group that claimed worldwide attention during the Cold War with groundbreaking achievements, far from being harmful, Stalinism fostered Soviet science.

The works of Alexei Kojevnikov and Slava Gerovich, both Russians based in North American universities, are part of an ongoing agenda which can be seen as the aftermath of the integration of Russian historians of Science in North America, and likewise, points to the integration of the history of Soviet science with the general history of science and technology. ${ }^{48}$ For example, Kojevnikov has called for, and developed, studies that compare the history of science in Russia to history of science in other national contexts, specially the United States, and cast light on how information, ideas, and scientific approaches have crossed and influenced scientists on both sides of the Iron Curtain. ${ }^{49}$ Konstantin Ivanov, studying the changes in Soviet science after Stalin's death, have claimed attention to the convergent attitude of Soviet and American physicist in the 1950s — while the Soviets were moving from applied to fundamental science, the Americans were moving in the opposite direction, from basic to applied science. Ivanov suggests to look into the impact of that convergence on science in both countries. ${ }^{50}$

Kojevnikov and Ivanov's suggestions are in resonance with more recent works that advocate for a transnational approach in history of science as a way of articulating the results of many local narratives and to think the history of science on a global level. ${ }^{51}$ With the renewed interest in debates about science, politics, and ideology that followed the Cold War many studies have scrutinized the development of science and the role of scientists as political players in contexts as diverse as Soviet Union, United States, East and West Germany, Brazil under military rule, and communist China. ${ }^{52}$ Those works have forged sophisticated historical narratives that mobilize ideological, political, and cultural factors to account for the historical development of science in specific contexts. ${ }^{53}$ They illustrate Olival Freire Jr.'s conclusion that "the job of the historian is therefore to disentangle the role played by each factor in each local and 
temporal context." ${ }^{\prime 54}$ As a whole, they reflect the emergence of the cultural and social history of sciences, and after all, the increasingly self-identification of historians of sciences as historians.

\section{Rewriting history}

The evolution of perspectives on Stalinism in the last half century seems to reflect Christopher Hill's assertion that "History has to be rewritten in every generation, because although the past does not change the present does; each generation asks new questions of the past, and finds new areas of sympathy as it re-lives different aspects of the experiences of its predecessors. "5ㅏ Perhaps the way we look at history tells us as much about our own times as about the historical moment in question.

The need for rewriting history became apparent to me in my own work on history of lasers in the USSR when I first read Loren Graham's last book, Lonely Ideas, about invention and innovation in Russia, which contains a chapter on lasers. ${ }^{56}$ It's difficult to say anything but prizes about a book that is "based not only on a study of the relevant sources but also on long-term residence in Russia, visits to dozens of Russian universities, research institutes, and industrial establishments, and conversations with thousands of scientists and engineers. ${ }^{\text {"57 }}$ The book is indeed masterfully written and reflects Graham's life-long experience and solid knowledge of Soviet sciences in the broad sense of the Russian word nauki, which includes all fields of scholarship. However, while acknowledging and respecting the authority and quality of the work, we need not agree with all of its underpinnings. Graham's book, besides being based on his lifelong experience as historian of Soviet science, is also based on a "rich literature on innovation"58 - I would add neoliberalwhich underlies many of his conclusions along the book. For instance, he gives as an evidence that the Soviet laser research lagged behind the statistics that "By the year 2000, approximately $\$ 200$ billion worth of lasers and laser systems had been sold. Yet the Russian share of the world laser market at this time, thirty-six years after two Russians and an American were awarded the Nobel Prize for the invention of the maser and laser, was merely 1-1.5 percent." ${ }^{\prime 59}$

While it may seem all right, given the purpose and intended audience of the book, to use dollar-based revenue to evaluate the success of laser innovation in Russia, it is problematic to use it to access laser innovation in the Soviet Union. First, Soviet laser research and development was based on a network of state-run, non-market institutions. The state was at the same time sponsor, producer, and the main consumer of laser-based technology. Using market indicators to access non-market institutions is, at best, misleading. How were the financial transactions accorded between those institutions? Were the price fixed to cover the costs of production or to generate profit? Can we estimate the revenues raised by laser $R \& D$ in the Soviet Union without including state investments on scientific and technological institutes and goal-oriented projects for specific applications of laser technology, a significant parcel of which was directed to classified projects? There are no easy answers to these questions. We need a more careful and refined analysis, which aims to understand the patterns of innovation in Soviet Union in its own terms to access how successful was laser research and development in the Soviet Union.

Russia's transition to a market economy did not happen overnight. As historians have argued, the collapse of Soviet Union did not end in 1991, but petered out at least until 2000, comprising much more than the emergence of civil society and adoption of neoliberal reforms. For Stephen Kotkin, for example, "What happened in the Soviet Union, and continued in Russia, was the sudden onset, and then inescapable prolongation, of the death agony of an entire world comprising non-market economics and anti-liberal institutions." 60

Besides, for Graham the impossibility of becoming super rich with inventions, what happen with laser inventors in the United States, was a setback to innovation in the Soviet Union. "Because of its centralized economy the Soviet Union could not develop laser companies in the individualistic, competitive, and, yes chaotic way in which they arose in the United States." He gives the example of "Valentin Gapontsev, whose story comes strikingly close to a start-up tale." ${ }^{61}$ A Soviet physicist specialist on light and lasers, when the Soviet Union collapsed, Gapontsev, illegally, establi- 
shed a private business in the basement of a small laboratory in the Institute of Radio Engineering in Friazino, a state institute near Moscow. Gapontsev began to do business with Italian companies and moved to Italy to open a business of his own. Soon his company was manufacturing high power fiber lasers and amplifiers in Italy and Germany. After his business run into trouble around 2000, Gapontsev decided he "had to move to the US, because a lot of business is based there." By 2006 his company, headquartered in Oxford, Massachusetts, had grown to \$143 million. ${ }^{62}$

The story above may be held as prove that the American Dream, however seldom, does come true. In fact, many inventors, even Soviet ones, may have been motivated by the prospect of fast enrichment ${ }^{63}$. However, that is by no means the only way of fostering innovation, and far not the most beneficial to society as a whole. A living example that there are effective ways to promote innovation besides profit-driven entrepreneurship is found in the story of the Soviet physicist Zhores Alferov.

Alferov was awarded the 2000 Nobel Prize in physics for the invention of semiconductor heterostructures that permitted the miniaturization of electronics and the creation of the first laser to operate continuously at room temperature, an invention to which we should be thankful whenever we use our small devices or listen to CD or DVD players. ${ }^{64}$ In any account, Alferov's life is plenty of episodes that illustrate how his commitment to communist values drove him toward innovations. For example, in the 1950s, he and other students of the Leningrad Physical-Technical Institute helped to design a power station and worked in several brigades in competition with each other to push the project forward, a strategy typical of the times of building socialism in the 1930s (when whole cities were built from scratch), then it was being employed to build communism. Efforts like that resonated with Alferov's faith in the power of science and technology to transform society. To this day, he is still an active communist and champion of science and technology. For him, communism now means primarily the defense of social welfare, public education and healthcare, and last, but not least, the revival of Russian science and hi-tech industry. Probably, Alferov's story is as rare as Gapontsev's. However, if I had to choose one to hold as a model for posterity, I would choose Alferov's. ${ }^{65}$

Graham's book is a remarkable guide of how to bring Russia closer to an idealized model of American liberal society. A model which, when seen against the background of works of critical thinkers as Noam Chomsky, seems very far and getting is increasingly further from reality. It is unlikely that young historians nowadays, feeling the effects of neoliberalism under their own skin, would take up such agenda. On the contrary, the historiography of Soviet Union in the twenty-first century seems to be going in the opposite direction. Venturing to discuss how the Soviet Union may look like in the twenty-first century, Fitzpatrick guesses that "'what was right with it' may be next on the agenda."66

Whereas the totalitarians, writing in a moment of anti-communist hysteria of the 1950s, were excessively concerned with demonstrating the ruthlessness of Stalinism, the revisionists, experiencing the power of popular mobilization exhibited in the protest of the 1960s, understood that Soviet people ought to have played a role larger than had been granted to them in totalitarian accounts. The post-revisionists, in turn, writing in a moment of increasing social insecurities, amid talks of crisis of academia due to the unrivaled influence of neoliberalism, have turned their attention to some of the legacy of the Soviet Union that had been taken for granted, such as the welfare state, a "bedrock of the world in which we live that today is coming apart everywhere," ${ }^{67}$ as Stephen Kotkin perceived in 1997. The North American academia is increasingly aware of the negative impact of neoliberal policies in our society, clearly visible in the academic intuitions themselves, ${ }^{68}$ an awareness that has extrapolated the intellectual circles and reached the general public, as revealed by the Occupy protests against soaring inequality that spread throughout North America and some European countries few years ago.

Perhaps one more lesson may the taken from the evolution of historical works on the Soviet Union. Acquiring professional maturity in times of collective awareness about the shortcomings in their societies seems to have helped both the revisionists and post-revisionists to assume a less condescending and more perceptive historiographic stances. Being self-critical, it seems, we are more inclined to adopt a more understanding, less judgmental stance in our analysis of other times and societies, and hence be more open to seeing their positive sides, as well as the negative ones. That, no doubt, has had a positive impact on historical studies of Soviet Union, as we can see by the rich, insightful, and interesting accounts of Soviet culture and society produced by both schools so far. 


\section{Notes and references}

Climério Paulo da Silva Neto is at the Universidade Federal do Oeste da Bahia, Barra, Bahia, Brasil. E-mail: cpsneto@gmail.com.

1 I would like to thank Breno Brito, Thiago Hartz, and Olival Freire Júnior for comments on earlier versions of this essay. This paper is a result of my Ph.D. studies at the Universidade Federal da Bahia and at the University of British Columbia under the supervision of Olival Freire Júnior and Alexei Kojevnikov. Olival has been my adviser since the second year of my undergraduate studies and I am greatly indebted for his continued mentorship and friendship. This research was financially supported by the Coordination for the Improvement of Higher Education Personnel (CAPES), the American Institute of Physics, and the University of British Columbia.

2 "Non ridere, non lugere, neque detestari, sed intelligere". Baruch Spinoza, Tractatus Politicus.

3 GRAHAM, Loren. What Have We Learned About Science and Technology from the Russian Experience? 1st edition. Palo Alto: Stanford University Press, 1998

4 KOJEVNIKOV, Alexei. Stalin's Great Science: The Times and Adventures of Soviet Physicists. London: Imperial College Press, 2004, p. 277.

5 For this methodological choice of discussing the dominant historiographic trends, I set aside works that do not dialog with the historiography of Soviet Union. Many of then, as those by historian Helge Kragh, are more history of specific theories or disciplines, cosmology in his case, than history of Soviet science. Some of these works were discussed recently by BAGDONAS, Alexandre; ZANETIC , João and GURGEL, Ivã. Controvérsias sobre a natureza da ciência como enfoque curricular para o ensino da física: 0 ensino de história da cosmologia por meio de um jogo didático. Revista Brasileira de História da Ciência, v. 7, n. 2, p. 242-260, 2014. That work is already an effort published in this journal to explore the lessons on the nature of science that we can learn about the nature of science from the Soviet experiment. Likewise, another recent paper presents an overview of Russian science from 1917 to 2010 : SANTOS JUNIOR, R. L. Dos. Análise histórica da evolução e desenvolvimento dos campos da Ciência e da Tecnologia na antiga União Soviética e Rússia ( 1917-2010 ). Revista Brasileira de História da Ciência, v. 5 n. 2, p. 279-296, 2012. My essay differs substantially in content and approach. While SANTOS JUNIOR (2012) is a longue dureé synthesis, this essay is more concerned with historiographic trends in history of Soviet science as a discipline.

$6 \quad$ KOJEVNIKOV, 2004, op. Cit., p. 277

7 See Revista Brasileira de História da Ciência, v.6, n.2. p. 151-248, 2013.

8 ENGERMAN, David C. Social Science in the Cold War. Isis, v. 101 n.2, 2010, p. 397. Indeed the work was considered to be so successful that the so-called area studies, such as Brazilian studies, Latin American studies, Asian studies and so on, proliferated in North American universities nourished by military money. Nowadays, when the Cold War passions are past, some US social scientists still few embarrassed about their role in producing work that was either sponsored by or proved to be useful to US defense and intelligence operations. A diagnose of the embarrassment and a defense of Cold War social sciences is presented in WOLFE, Audra J. Cold War Social Science. berfrois.com, 2013

9 The totalitarian framework is discussed in FITZPATRICK, Sheila. New perspectives on Stalinism. Russian Review, v. 45 n. 4, 1986; HALFIN, I. and HELLBECK, J. Rethinking the Stalinist Subject: Stephen Kotkin's" Magnetic Mountain" and the State of Soviet Historical Studies. Jahrbücher für Geschichte Osteuropas, v. 3 ก. 44,1996

10 See introduction of KOJEVNIKOV, 2004, op cit.

11 One of the purposes of Engerman's essay is to show that work produced in area studies, even those directly financed by military agencies, were not always aligned with military needs and expectations, and produced valuable knowledge on cultures around the world. Soviet history, as developed in North American universities, is a case for this argument. ENGERMAN 2010, op. cit.

12 Economy cost of a project is measured using the relative share of a project as a percent of the output of the economy. It reveals the importance of the project to society as a whole. See http://www.measuringworth.com/uscompare/relativevalue.php. Acessed on Dec 27, 2014.

13 ENGERMAN, 2010, op. Cit., p. 399. The partial results of the project were presented in BAUER, Raymond Augustine; INKELES, Alex and KLUCKHOHN, Clyde. How the Soviet System Works: Cultural, psychological, and social themes. Cambidge: Harvard University Press, 1956. Summaries of the interviews are available on line in the page of The Harvard Project on the Soviet Social System: http://hcl.harvard.edu/collections/hpsss/. Acessed on 0ct 03, 2016.

14 http://www.rand.org. Acessed on Dec 27, 2014.

15 ENGERMAN 2010, op. cit., p. 399

16 Khrushchev took a series of actions to signal to the world that Soviet Union was heading on a path different of that settled by Stalin and to amend the damaged caused by the impact of his Secret Speech and the subsequent crack down on Hungarian protests. For instance, during the 1957 World Youth Festival more than 30.000 foreigners where received in Moscow in a peaceful and open atmosphere. The festival is regarded as a mark of the opening of the Soviet Union to the outside world, a redefinition of relationship between Soviet people and foreigners, and part of the revival of Soviet cultural relations that climaxed with the signing of an agreement on cultural exchange between the United States and the Soviet Union in 1958. See KOIVUNEN, Pia The 1957 Moscow Youth Festival: propagating a new peaceful image of the Soviet Union. in: ILIC, Melanie editor, Soviet State and Society under Nikita Khrushchev. London and New York: Routledge, 2009. - chapter 3.

17 As an indication that in the 1960s the two great powers increasingly resembled each other for contemporaries, in the late 1950s and early 1960s there appeared a number of convergence theories, according to which all developing industrial societies, independent of their political composition, are confronted principally with the same social prerequisites and challenges, and would converge in their social, political and economic systems because of the determinant effects of technological development. For a summary of some convergence theories see REQUATE, Jörg. Visions of the Future: GDR, CSSR, and the Federal Republic of Germany. In: HAUPT, Heinz-Gerhard and KOCKA, Jürgen (ed.), Comparative and Transnational History: Central European Approaches and New Perspectives. Berghahn Books, 2012. Chapter 8, p. 181-183.

18 FITZPATRICK, 1986, op. cit.

19 From 1918 the Bolsheviks loosened requirements for university admission, abolished formal titles and diplomas, and created a series of affirmative actions 
to populate universities with students from formerly unprivileged or discriminated groups - peasants, workers, women, and racial minorities. Fitzpatrick called Cultural Revolution the apex and end of that process, raging approximately from 1928, when young radical students were stimulated to challenge the authority of their professors, until 1934, when the expansion was reined in, titles were restored, and the new system became focused in quality and discipline. See: FITZPATRICK, Sheila. The Cultural Front: Power and Culture in Revolutionary Russia (Studies in Soviet History and Society). Ithaca: Corn University Press, 1992. An example of the impact of those policies on the lives of Soviet scientists is given in KOJEVNIKOV, Alexei. A Grande Ciência de Stalin: Tempos e Aventuras de Físicos Soviéticos no Exemplo da Biografia Política de Lev Landau. Revista Brasileira de História da Ciência, v. 4 n. 1, 2011. historiography and their emphasis on interest see HALFIN and HELLBECK. The symmetry principle, for Edinburgh school, implied that the same factors should be used to explain both the success and failures of scientific enterprises. For a discussion of interest and symmetry as guiding principles of the Edinburgh school see HACKING, lan. The Social Construction of What? Harvard University Press, 1999, p. 90. Another common ground between revisionists and sociologist of science seems to be their debit to Thomas Kuhn's influential The Structure of Scientific Revolutions (1962). Fitzpatrick later wrote: "many natural scientists - believing their disciplines to be cumulative and their generalizations to be falsifiable in principle and in practice by new experimental data - have problems with the Kuhn argument, whereas social science and humanities people love it." FITZPATRICK, Sheila. The Soviet Union in the twentyfirst century. Journal of European studies, v. 37 n. 1, 2007, p. 66.

22 GRAHAM, Loren R. Science, Philosophy, and Human Behavior in the Soviet Union. New York: Columbia University Press, 1987, p. xi.

23 Ibid., p. $x$

24 GRAHAM, Loren R. Science in Russia and the Soviet Union: A Short History. Cambridge University Press, 1993.

25 BAILES, Kendall E. Technology and Society under Lenin and Stalin: Origins of Soviet technical intelligentsia, 1917-1941. Princeton: Princeton University Press, 1978.

26 BAILES, Kendall E. Science and Russian Culture in an Age of Revolitions: V. I. Vernadsky and his scientific school, 1863-1945. Bloomington and Indianapolis: Indiana University Press, 1990, pp. 160-178, chapt. 5

27 For a self-critical acknowledgment of the revisionist's inability to abandon the Sovietological questions see: FITZPATRICK, 1986, op. cit.

28 A good criticism of revisionist historiography can be found in HALFIN and HELLBECK, 1996, op. cit.

29 The new portraits of Lenin and Stalin based on archives opened in the 1990s are discussed in FITZPATRICK, 2007, op. cit. p. 54.

30 KOTKIN, Stephen. Magnetic Mountain: Stalinism as a Civilization. 1st edition. Berkeley, Los Angeles, Oxford: University of California Press, 1997, p. 6.

31 HALFIN and HELLBECK, 1996, op. cit.

32 FITZPATRICK, 2007, op. cit.

33 KOJEVNIKOV, Alexei Introduction: A New History of Russian Science. Science in Context, 15 2002:2.

34 For the new interpretation of Soviet history see FITZPATRICK, 2007, op. cit.; HALFIN and HELLBECK, 1996, op. cit.

35 FITZPATRICK, 2007, op. cit., p. 52. In works in history of Soviet science that tone may be found, for example, in GORELIK, Gennady. Lev Landau, Prosocialist Prisoner of the Soviet State. Physics Today, 48 1995:5 URL: people.bu.edu/gorelik/Landau\_PhysicsToday\_1995.htm; JOSEPHSON, Paul R. Physics and politics in revolutionary Russia. University of California Press, 1991.

36 FITZPATRICK, 2007, op. cit., p. 60. Ideology was already an essential element of the totalitarian framework. However, it was seen and imposed by the state on its population. The post-revisionists, in turn, view ideology as shaped by both state and its citizens. This way they combined elements of both frameworks HALFIN and HELLBECK, 1996, op. cit.. Seeing the work of entire generations in general trends we risk committing some injustices. I would like to amend at least one by acknowledging that Loren Graham, discussed here as a revisionist, payed due attention to Marxism-Leninism and a driving force behind Soviet science.

37 KOTKIN, 1997, op. cit

38 KOJEVNIKOV, 2004, op. cit, pp. 186-216.

39 KOTKIN, 1997, op. cit., p. 19

$40 \quad$ Ibid., p. 22.

41 I have drawn this conclusion from Fitzpatrick's comment: "Kotkin's subtitle, Stalinism as a Civilization, was one that in earlier years no revisionist would have dared to use for fear of being accused (however inaccurately and unfairly) of being a Stalinist." FITZPATRICK, 2007, op. cit., p. 61.

42 For Big Science see KOJEVNIKOV, 2004, op. cit., pp. 23-46. Kojevnikov convincingly argues that the Soviet model of science can be seen as the precursor of what would be later labeled Big Science, and influenced science in countries such as France, England, and indirectly, the United States. When British physicists began working on the radar project at the beginning of the WWII they called their weekly meetings the "Sunday Soviet". KOJEVNIKOV, Alexei. The Phenomenon of Soviet Science. Osiris, 23 2008. For a discussion of welfare state see KOTKIN, 1997, op. cit. , p. 21. Kotkin argues that under Stalin the state-guaranteed social welfare was developed to a greater extent than had previously been the case anywhere, and that "the Soviet example, as showcased in Magnitogorsk, could be said to have exerted a direct and profound influence on the rest of the world's industrialized countries. In a word, the USSR decisively shaped part of the bedrock of the world in which we live, a bedrock that today is coming apart everywhere." Affirmative actions are discussed in MARTIN, Terry. The Affirmative Action Empire: Nations and Nationalism in the Soviet Union, 1923-1939. Ithaca: Cornell University Press, 2001.

43 FITZPATRICK, 2007, op. cit.

44 Yuri Slezkine has challenged the Western assumptions that the history of Jews in Soviet Union is purely a victim story, showing that the upward mobility of Jews after the revolution constituted an important source of support for the regime. However, when antisemitism grew in the late 40s an increasing number of Jews withdrew their support, some of who would later dissent. See: SLEZKINE, Yuri. The Jewish Century. Princeton University Press, 2006.

45 For war veterans, stiliagi, and the attitude of other groups of Soviet society to the regime and its policies in late Stalinist Soviet Union see essays in the volume FÜRST, Juliane. Late Stalinist society: history, policies and people. in: FÜRST, Juliane (ed.). Late Stalinist Russia: Society Between Reconstruction and Reinvention. London and New York: Routledge, 2006. 
47 KOJEVNIKOV, 2004, op. cit., pp. xi- xii. This approach is presented also in KOJEVNIKOV, 2011, op. cit. For a review of Stalin's Great Science see FREIRE JR., Olival. RESENHA: Stalin's Great Science: The Times and Adventures of Soviet Physicists (Alexei Kojevnikov). Revista Brasileira de História da Ciência, v.03, n. 02, 2005.

48 KOJEVNIKOV, 2002, op. cit.

49 KOJEVNIKOV, 2004, op. cit., pp. 276-300.

50 IVANOV, Konstantin. Science after Stalin: Forging a New Image of Soviet Science. Science in Context v. 15, n. 02, p. 317-338, 2002. In a forthcoming article with Alexei Kojevnikov, I discuss the convergence of Soviet and American physics under an atmosphere of increasing militarization in the early Cold War, approaching themes that have been widely discussed in the historiography of science as the militarization, secrecy, and the compartmentalization of knowledge. SILVA NETO, Climério Paulo and KOJEVNIKOV, Alexei. Convergence of Cold War Science: Co-inventing the maser in the Soviet Union. (forthcoming).

51 See the special issue of the British Journal for History of Science dedicated to historiographic reflections on the approach: TURCHETTI, Simone; HERRAN, Néstor; and BOUDIA, Soraya. Introduction: have we ever been 'transnational'? Towards a history of science across and beyond borders. The British Journal for the History of Science, v. 45 n. 03, p. 319-336, 2012.

52 Collective efforts by historians of science from different countries was a strong evidence of the prominence of the topic. See essays in the special issue Physicists in the Postwar Political Arena: Comparative Perspectives, Historical Studies in the Physical and Biological Sciences, vol. 30, n. 1, 1999. Also, the chapters in the book WALKER, Mark (ed.), Science and Ideology: A Comparative History. New York: Routledge, 2003.

53 Examples of works in this line may be found in FREIRE JR., Olival. The Quantum Dissidents: Rebuilding the Foundations of Quantum Mechanics (19501990). Springer, 2015; KOJEVNIKOV, 2004, op. cit. I have also to pay due tribute to a longer historiographic tradition dating back to the 1970s represented by historians such as Paul Forman and John Heilbron. Historians of both old and new generation are well represented in the volume CARSON, Cathryn; KOJEVNIKOV, Alexei; and TRISCHLER, Helmuth (ed.), Weimar Culture and Quantum Mechanics: Selected Papers by Paul Forman and Contemporary Perspectives on the Forman Thesis. London; Singapore, 2011.

54 FREIRE JR., Olival. Quantum dissidents: Research on the foundations of quantum theory circa 1970. Studies In History and Philosophy of Science Part B: Studies In History and Philosophy of Modern Physics, v. 40, n. 4, 2009, p. 281.

55 HILL, Christopher. The World Turned Upside Down. Penguin Books, 1984. p. 15.

56 GRAHAM, Loren R. Lonely Ideas: Can Russia Compete? Ebook. Cambridge: MIT Press, 2013. See chapter 9.

57 Ibid. location 118

$58 \quad$ Ibid. location 97.

59 Ibid. location 1653

60 KOTKIN, Stephen. Armageddon Averted: The Soviet Collapse, 1970-2000. Oxford University Press, 2008, p. 2

61 GRAHAM 2013, op. cit., location 1686.

62 GRAHAM 2013, op. cit.

63 See for example the case of Gordon Gould in HECHT, Jeff. Beam: the race to make the laser. New York: Oxford University Press, 2005, Chap. 4.

64 KOJEVNIKOV, Alexei. A Nobel for communism. Physics World, March 2011

65 For Alferov's biography see: JOSEPHSON, Paul R. Lenin's Laureate: Zhores Alferov's Life in Communist Science. MIT Press, 2011; ALFEROV, Zhores I. Nauka i Obshchestvo. Sankt-Peterburg: Nauka, 2005; idem, Zhores I. Alferov - Biographical. 2014

URL: http://www.nobelprize.org/nobel\ prizes/physics/laureates/2000/alferov- bio.html. For a description of the enthusiastic building of socialism in the 1930s see KOTKIN, 1997, op. cit. The importance of Alferov's invention and his communist views are discussed in KOJVNIKOV, 2011, op. cit.

66 FITZPATRICK, 2007, op. cit., p. 64.

67 KOTKIN, 1997, op. cit., p. 22.

68 Recently there appeared many articles and blog posts about the harmful influence of neoliberal policies in North American colleges and universities. Professors from top US universities such as Columbia have given this kind of advice to students: "I won't talk to students about graduate school anymore... Going to grad school's a suicide mission." For a highly discussed article on this issue see: DERESIEWICZ, W. Faulty Towers: The Crisis in Higher Education. The Nation, 2011.

Available at: http://www.thenation.com/article/160410/faulty-towers-crisis-higher-education\# Accessed on October 3, 2016.

[Recebido em Junho de 2015. Aceito para publicação em Julho de 2016] 